\title{
MARSHALING THE COURT: LEADERSHIP, BARGAINING, AND THE JUDICIAL PROCESS*
}

\author{
WALTER F. MURPGY
}

$\mathrm{T}$

THE AMERICAN system of government, with its roots in the common law tradition, imposes a number of limitations on the power of an individual Supreme Court Justice. One of the more obvious of these restrictions is that a Justice shares decision-making authority with eight other judges. To have any policy, even that of self-restraint, officially accepted as the Court's, a Justice must first of all persuade at least four of his colleagues not only to vote with him in conference but also to join with him in an institutional opinion setting forth the necessary principles. Moreover, since a fivefour decision may serve to emphasize the unsettled nature of the doctrine involved, and so encourage opposition to it, a Justice has a strong incentive to secure more than simple majority acquiescence.

This paper is a discussion of means, not of ends. Its purpose is to analyze some of the major strategies and tactics which are open to a Justice to mass the Court behind his views on controversial issues of public law and policy. Several assumptions will be made. First, the ends for which the Justice is working are presumed to be compatible with the historic role the judiciary has played in American government as well as with the basic values of a free society. Second, since ends do not justify means, it is further assumed that the Justice will not act illegally. There will be no discussion of such tactics as bribery, lying, or threats or use of unlawful violence. The integrity of American judges makes these first two assumptions quite realistic.

The third assumption is that the Justice-deeply believes that his goals of legal policy are important to the Court, to the legal system, and to the country, and that he would prefer seeing these goals actually achieved, though perhaps imperfectly, over merely writing solitary essays instructing future generations about current folly-although, of course, it may well turn out that under some circumstances he has no other choice. Fourth, it is assumed that the Justice will act rationally-rationally in terms of the particular ends involved, not in terms of personal gain, reputation, or pleasure. It cannot be denied that men neither do nor can always act rationally. Furthermore, deliberate irrationality may be rational in a given situation, as game theorists

*I am indebted to the Social Science Research Council for subsidizing my research into the Stone, Taft, Sutherland, McReynolds, Hughes, and Lurton papers.

f Associate Professor of Politics, Princeton University. 
delight in pointing out. ${ }^{1}$ Still, we must begin by trying to understand rational behavior, even though we cannot afford to stop there.

Several disclaimers are also in order. First. this paper does not assert that judges always or frequently do act in the fashion to be described. The thesis is only that judges, if they are to act rationally; must weigh all the alternatives which are to be discussed - and many that are not. Second, when examples of prior judicial actions are cited, there is no attempt to imply that the Justices concerned acted from any but the very highest of motives, or that these actors even realized, much less intended. the power implications of what they were doing. These examples serve only to show that strategies and tactics which are theoretically applicable are also practically possible; they are not designed to impute motives to the actors.

\section{I.}

Research into the behavior of small. experimental groups has led some sociologists to distinguish between "task" and "social" leadership. 2 The task oriented leader, as his title implies, is concerned with getting a job done. He tends to ignore personal relations and instead to rivet his attention on the efficient solution of problems which confront the group. On the other hand, the socially oriented leader provides the warmth and friendliness which make interpersonal relations pleasant or eren possible. He tends to raise the selfesteem of other members of the group, to accept suggestions readily, to be quick to relieve tensions with a laugh or a friendly joke. Small groups researchers have rarely found in a laboratory environment one person exercising both functions of task and social leadership. 3

It is doubtful if evidence gathered from experimental-or even many formal groups-can be carried over without modification to the judicial process. Judges on a collegiate court may be thrown together by chance factors, but they work within a well-defined and peculiar tradition and have to look forward to a long future of cooperation-or conflict-with their peers.

I See Schellivg. The Strategy of Cosflict 16-19, 143 (1960).

2 This distinction is one which has been largely dev eloped out of the work of Prof. Robert F. Bales. See his INteraction Process Avilysts: A Mifthod for the StIDy of Silall Grolps (1950). Prof. David Danelski first applied this concept of dual leadership functions to judicial behavior in The Influence of the Chief Justice in the Decisional Process of the Supreme Court (unpublished paper presented to the 1960 meeting of the American Political Science Association). A shorter version of this paper appears in MLrPHY \& PRITCHETT, COLRTS, JUDGES AID POLITICS 497-508 (1961).

There is a great volume of literature on leadership and small groups. Particularly helpful are: Bass, Leadershim, Psychology, asd Orgastzational Behaitor (1960); GolembiehsXi, The SMall GrotP (1962), and Behaltor and Organtzation (1962); Hare, borgatta, \& Bales, Small Grolps: Stcdies in Soclat Iiteraction (1955); Verba, Small Grolps ANd Political Behaitor: A STLdy of Leadership (1961). Interesting for the study of the Court is Snyder, The Supreme Court as a Small Group, 36 Soclal FORCES 232 (1958).

${ }^{3}$ See the literature cited by VERBA, op. cit. supra note $2, \mathrm{ch} .7$. 
Nevertheless, the task-social leadership dichotomy can serve to put on a firmer empirical basis the common sense observation that a man who wishes to exert influence over his fellows can do so most effectually if he is both intellectually disciplined and tactful in interpersonal relations.

By being aware of this fact, a Justice may be able to adopt more successful strategies. On the other hand, mature men whose personalities have been shaped by many years of experience rarely have the capacity completely to remould their characters, no matter how deep their understanding of social psychology. Indeed, some Justices might have no real choice at all in the matter. Many Justices may be unable to envision any alternative to "bullying" their way through. Speaking of a colleague Justice Jackson told Arthur Krock in 1947 that "you just can't disagree with him. You must go to war with him if you disagree." 4 Jackson was hardly a dispassionate critic of the Justice involved; but, whether accurate or not insofar as a particular Justice was concerned, Jackson's description does fit a common personality type. Many men who become committed to an idea become totally committed -and bitterly suspicious of all opposition. Other Justices at the opposite end of the personality spectrum may simply try to fiatter their colleagues and then attempt to cash in on whatever capital this has built up. Neither tactic, standing alone, offers much promise in dealing with eight sophisticated lawyers whose careers have usually included considerable experience in practical politics. 5

Even if a single Justice did not possess both qualities of task and social leadership talent, he might still ally himself with another Justice so that their combined abilities might fulfill both leadership functions. Chief Justice Taft recognized his own intellectual limitations and perceived a way of achieving influence. He told his son in 1925: "I find myself constantly exposed to the humiliation of not discovering things in cases, especially in matters of jurisdiction which are very intricate and most exasperating."' 6 Two years later he again complained that the other Justices "have more time than I have, and sometimes they humiliate me with their pointing out matters that I haven't given time enough to the cases to discover. The familiarity with the practice and the thoroughness of examination in certain cases that Van Devanter is able to give makes him a most valuable member of the Court and makes me feel quite small, and as if it would be better to have the matter run by him alone, for he is wonderfully familiar with practice and our authorities."7 Taft, how-

4 Gerhart, Americh's Advocate: Robert H. Jackson 274 (1958).

5 For a comparative study of the social and political backgrounds of Supreme Court Justices, see Schmidhauser, The Justices of the Supreme Court: A Collective Portrait, 3 MidWEST J. POLITICAL SCIENCE 1 (1959).

6 Letter from William Howard Taft [hereinafter referred to as WHT] to Robert A. Taft, Jan. 25, 1925, the Taft papers, on file in the Library of Congress.

7 ld., WHT to R. A. Taft, Oct. 23, 1927. 
ever, was shrewd enough to utilize Van Devanter's learning-there are numerous notes in the Taft papers from the Chief Justice asking Van Devanter to look over an opinion before Taft circulated it to the Court-and develop his own ability to exert social leadership. As he said in closing his letter to his son, "Still I must worry along until I get to the end of my ten years, content to aid in the deliberation when there is a difference of opinion." 8

It is not at all unlikely that a judge cannot forge a coalition which would allow performance of both functions. The Justice's natural allies on doctrinal matters might have the same attributes and suffer from the same failings. ${ }^{9}$ Even so, the very fact of being aware of the two aspects of leadership might allow the judge to evaluate his colleagues with greater perception.

II.

If, as some of the studies of formal groups indicate, established authority creates an expectation that both task and social leadership will be exercised by the titular leader, 10 it would follow that the Chief Justice should enjoy a great initial advantage." The Chief Justice, as Taft once wrote, "is the head of the Court, and while his vote counts but one in the nine, he is, if he" be a man of strong and persuasive personality, abiding convictions, recognized by learning and statesmanlike foresight, expected to promote team-work by the Court, so as to give weight and solidity to its opinions." 12

The Chief Justice presides in open Court and more important at the conference. He is then given an opportunity to exercise task leadership by stating his views first on cases and, as Hughes usually did, selecting the issues to be discussed. As presiding officer he may also exert social leadership. He may have the Court dispose of the less controversial decisions before taking up those more likely to cause dissension. By tackling these simpler items first a higher degree of harmony 13 could be established which might carry over and protect later discussion from personal rancor. If and when argument begins to get heated, the Chief may use his authority to ease tension, either by cutting off debate or soothing hurt feelings. Hughes would often end a discussion

8 Ibid.

9 It might be that a judge who was intensely ambitious for the success of a given doctrine would be more likely to be task rather than socially oriented. Still it is possible, as with Taft, that his social leadership skills can be far stronger than his intellectual ability.

10 Consult the literature cited in VERBA, op. cit. supra note 2, at 170. See Berkowitz, Sharing Leadership in Small, Decision-Making Groups, 48 J. ABNormal \& Social PsycholOGY 231 (1953).

11 See the Danelski papers, supra note 2, and the forthcoming study of the office and powers of the Chief Justice by Prof. Alpheus T. Mason.

12 Draft of a tribute to Edward D. White, c. May 1921, op. cit. supra, note 6.

13 "Viscidity" and "hedonic tone" are the terms which small group sociologists seem to prefer to describe such characteristics of a group situation. See the literature cited in BASS, op. cit. supra note 2 , at $47,49$. 
which was threatening to get out of hand by saying, "Brethren, the only way to settle this is to vote." 14 When Melville W. Fuller was Chief Justice, Holmes once interrupted Justice Harlan's statement of his views with a caustic, "That won't wash!" Harlan, never noted for avoiding a fight, reddened, but Fuller quickly broke in: "But I keep scrubbing away, scrubbing away," using his hands as if rubbing clothes on a washboard. The laughter that ensued allowed the Justices to get back to their work without a bitter exchange of words.15

Much of the Chief Justice's initial advantage is postulated on the belief that his accepted, i.e., legitimate, role is one of leadership. This may or may not be true. Severe and efficient, Hughes, it would not be too much to say, dominated the conference. 16 Only rarely were matters discussed which he did not want brought up, and the Justice who dared debate with the Chief usually found himself in a very painful position since Hughes came into the conference armed both with heavily marked volumes of the U.S. Reports and a photographic memory. He also had a keen sense of humor, though he used it infrequently. Nevertheless, apparently no other member of the Court had the temerity to try to exert social leadership.

When Stone succeeded :Hughes, it is not unlikely that the Associate Justices had come to expect the Chief to act both as a task and a social leader. But Stone did not play either role, at least not in a fashion comparable to that of either of his immediate predecessors. Since he had felt frustrated by Hughes' methods, the new Chief Justice refused to cut off discussion-indeed, he joined in angry wrangling with his associates, something which Hughes considered beneath his station. Long, acrimonious harangues, which often stretched from Saturday until Wednesday, marked the Stone conferences.17

Harlan Stone held the center chair for five years, and his legacy to his successor was in all probability a changed concept in the minds of the Associate Justices of the Chief Justice's role. Thus if Vinson, assuming he had had the desire as well as the intellectual ability and social charm, had tried to return to the kind of leadership which Hughes had exerted, he might well have alienated his associates by violating their expectations of his proper role. It is

14 Quoted in Pusey, Charles Evans Hughes 676 (1951).

15 King, Melville Weston Fuller 290 (1950).

16 For Hughes' manner of presiding over the Court see Mison, HARLAN FisKE STONE: PuLAR of THE LAW 788-90 (1956) [hereinafter cited as MASON]; PUSEY, op. cit. supra note 14, at 672-78; Frankfurter, Chief Justices I Have Known, 39 VA. L. REv. 883 (1953); McElwain, The Business of the Supreme Court as Conducted by Chief Justice Hughes, 63.HARv. L. Rev. 5 (1949).

17 For Stone's concept of his role as Chief Justice see Mason, ch. 47. Sociological research has documented the common sense observation of most people who have had to do committee work: too much time spent in group discussion lowers satisfaction with the final decision. However, similar research contradicts the actual occurrence in the Stone Courtthat is, several sociologists claim that free discussion increases group coalescence, whereas the effect of the Stone Court was increased division and dissension. See the literature cited in BAss, op. cit. supra note 2, at 131-32. 
quite possible that for the immediate future Stone destroyed any aura of legitimacy surrounding the Chief Justice's position of leadership within the Court. This does not mean, of course, that such an aura could not be recreated. Hughes, for example, built up an expectation of task leadership which Taft had never exercised, and he did so with Van Devanter, the old task leader, still on the bench. John Marshall, of course, had to start with even less of a tradition than did Hughes and for almost twenty-five years achieved a degree of success which startled and dismayed his enemies.

Even where an expectation of leadership by the Chief Justice has been inherited or built up, the advantages conferred are not necessarily decisive. Both friendly and critical students of Marshall's reign agree that after 1825 he pretty well lost control over his Court.18 Hughes exploited his authority with superb skill, yet he could not prevent his colleagues from splintering into angry factions, or keep his Court from engaging in a wasted and almost suicidal war against the twentieth century. Nor could Hughes' great talents conceal the drastic nature of the reversal which the High Bench executed when it capitulated to the New Deal-though he was successful in masking the extent of his own backing and filling during the period 1935-37.19

The Chief Justice's power within the Court, like that of his associates, is also materially affected by the character of his colleagues. Justice William Johnson explained Marshall's influence largely in terms of the lethargy of the other Justices. As Johnson told Jefferson:

While I was on our state-bench I was accustomed to delivering seriatim opinions ... and was not a little surprised to find our Chief Justice ... delivering all the opinions in cases in which he sat, even in some instances when contrary to his own judgment and vote. But Y remonstrated in vain; the answer was he is willing to take the trouble and it is a mark of respect to him. I soon however found out the real cause. Cushing was incompetent. Chase could not be got to think or write-Patterson [sic] was a slow man and willingly declined the trouble, and the other two judges [Marshall and Bushrod Washington] you know are commonly estìmated as one judge. ... .20.

On the other hand, it is difficult to imagine any Chief Justice-even a Marshall or a Hughes-dominating for any length of time a Court composed of men as individualistic, brilliant, articulate, and strong willed as Hugo L. Black,

184 BeVeridge, The Life of Johr Marshali 480 ff., 512-14, 585 (1919); Haines, The Supreme Court in AMerican Government and Polimics, 1789-1835 579 ff. (1944); cf. Crosskey, Mr. Chief Justice Marstall in Mr. Justice 17 (Dunham \& Kurland eds. 1956).

19 See Hendel, Charles Evand Hughes and the Supreme Court 279 (1951). Pusey, op. cit. supra note 14, at 770-72, does not believe that Hughes did change. Pusey's reasoning and evidence, however, have been demolished by Mason in his Charles Evans Hughes: An Appeal to the Bar of History, 6 VAND. L. REV. 1 (1952). Cf. RoCHE, COURTS AND Rights 94 (1961): "Like General Douglas MacArthur, Hughes never retreated-he firmly advanced to the rear...."

20 Quoted in Morgan, Justice William Johnson: The First Dlssenter 181-82 (1954). 
William O. Douglas, Felix Frankfurter, or Robert H. Jackson. In such situations leadership becomes a more subtle matter:

III. -

This discussion raises the question of how a Justice is able to influence his colleagues. The first means is that of rational persuasion. To date all the Justices have been lawyers, and whatever the status of their technical knowledge when appointed, their work, their friends, their critics, their pride, and their clerks soon force them to become competent lawyers-in most instances highly competent craftsmen. Traditional overemphasis on the rational aspects of the judicial process has been exploded by the legal realists. Yet, it is true that judges may often be able to overcome their predilections and base their decisions on legal principles and precedents.

Furthermore, judges can be persuaded to change their minds. Robert Jackson once commented from the bench: "I myself have changed my opinion after reading the opinions of the other members of this Court. And I am as stubborn as most. But I sometimes wind up not voting the way I voted in conference because the reasons of the majority didn't satisfy me." 21 There are countless instances on record in which judges, assigned the opinion of the Court, reported back to their brethren that additional study had convinced them that the conference's vote had been in error. A few examples will have to suffice.

When in May, 1922, Taft circulated his opinion in Hill v. Wallace22 he attached a statement summarizing the history of the Court's handling of the dispute:

... we voted first that there was equitable jurisdiction by a vote of 7 to 1 , Justice Brandeis voting "No" and Justice Holmes being doubtful. On the question of whether [the congressional statute regulating trading in grain futures] could be sustained as a taxing act, the vote stood 7 to 1 , Justice McKenna casting the negative vote, and Justice-Brandeis not voting. Later. we took a vote as to whether the act could be sustained as a regulation of interstate commerce. At first, by a vote of 5-4, it was held that it could not be so sustained. Later there was a change, and by a vote of 5 to 3 , Justice Brandeis not voting, its validity as a regulation of interstate commerce was sustained.23

Then Taft pointed out he had changed his mind and asked the Court to go along with him. "On a close examination of the case, the law and the record, I have reached the conclusion that the law is invalid as a taxing law and that it can not be sustained as a valid regulation of interstate commerce."

21 Quoted in Westin, ANatomy of a Constitutional LaW Case 123-24 (1958).

22259 U.S. 44 (1922).

23 This memorandum, dated May 12, 1922, was addressed to all members of the Court except Justice Clarke. The U.S. Reports do not note that Clarke did not participate. The omission was probably due to an oversight by Taft's secretary. 
When the opinion came down three days later, the statute was declared unconstitutional as a taxing act, under the authority of the Child Labor Tax Case. ${ }^{24}$ The vote was eight-one, with Brandeis agreeing in a separate opinion that the statute was unconstitutional but doubting that the plaintiffs had standing to sue.

In March, 1945, a majority of the Court voted in conference to affirm the conviction under the Sherman Act of several employers and union officials who had conspired to raise wages and prices by trying to monopolize the lumber business in the San Francisco Bay area. 25 The opinion of the Court was assigned to Justice Black. On May 2, 1945, however, Black circulated an opinion reversing the convictions. Black explained that attention in conference had been focused on the question of the exemption of labor unions from anti-trust statutes. His study of the case had revealed that the trial judge had committed serious error in refusing to charge the jury in accordance with the provisions of the Norris-La Guardia Act. 26

Black may have been persuaded, but his colleagues were not, at least not immediately. The case was twice set down for reargument on the construction of the Norris-La Guardia Act, and the decision did not finally come down until March 10, 1947. The vote to reverse was five-three, Justice Jackson not participating. As the senior majority Justice, Black, possibly as a means of conciliation, assigned the opinion to Reed; and Reed held that the trial judge's charge to the jury had been erroneous under the Norris-La Guardia Act and ordered a new trial.

The fact that the original opinion writer changes his mind carries no automatic assurance that he will bring the Court with him. In Cramer v. United States, ${ }^{27}$ for example, Justice Black at first voted with a unanimous bench to reverse the treason conviction of a naturalized American citizen who had aided one of the Nazi saboteurs who during World War. II had landed in the United States from a submarine. After the conference in March, 1944, Stone assigned Black the task of writing the opinion of the Court, but two weeks later Black reported back to the Chief Justice that he had been unable to do so. Careful reading of the record had convinced him that Cramer had had a completely fair trial. Black concluded that only if an American citizen were actually found in the army of an enemy could a practical situation arise where the evidence of treason was more substantial. 28

24259 U.S. 20 (1922).

25 United Brotherhood of Carpenters v. United States, 330 U.S. 395 (1947). Cert. granted Jan., 1944 (323 U.S. 706); the case was first argued March 8, 1945; reargument was ordered June 18, 1945; the case was again argued on April 29, 30,1946, was set down for a second reargument on June 10, 1946, argued for the third time on Oct. 15, 16, 1946.

26 Hugo L. Black to Members of the Conference, May 2, 1945, the Stone papers, on file in the Library of Congress.

27325 U.S. 1 (1945).

28 Hugo L. Black to Harlan Fiske Stone [hereinafter referred to as HFS], March 25, 1944, op. cit. supra note 26. 
Black was not the only Justice who was having doubts, and after a delay of several months the case was set down for reargument. ${ }^{29}$ When the decision was finally announced in the spring of 1945 , the vote was five-four. The majority, speaking through Justice Jackson, ruled that the government had failed to meet the constitutional requirement for a treason conviction: testimony of two witnesses to the same overt act of "levying War" against the United States or "adhering to their Enemies." Black, along with Stone and Reed, joined in Douglas' dissent, charging the majority with deciding the case on a hypothetical rather than a real set of facts. "Such a result," the minority vainly protested, "makes the way easy for the traitor, does violence to the Constitution and makes justice truly blind." 30

IV.

Logic, however, is sometimes a frail instrument, especially when Justices reason from contradictory major premises. One other way of lessening the collegiate check on his power is for a Justice to take part in the appointing process. Gratitude on the part of the selectees might give the helping Justice a decided influence in cases where the selectees were unsure of themselves, particularly if their gratitude were coupled with deep intellectual respect. But gratitude, as Presidents since the time of George Washington have often painfully learned, is a weak influence on judges who possess what amounts to life tenure. More significant in increasing one Justice's power to shape the course of Court decisions would be his selection of men who tended to think as he did on issues he considered vital-or at least his keeping off the Court men with whom he tended to disagree on fundamentals. Judicial appointees have a habit of not fulfilling expectations-Stone once described the appointing process as "a lottery" 31 -but at least the helping Justice could have some rational basis for choice.

Many members of the Court have become embroiled in appointment politicking. Miller, ${ }^{32}$ Fuller, ${ }^{33}$ and Brown ${ }^{34}$ tried it with varying degrees of success, but the most systematic efforts along these lines were made by William Howard Taft. ${ }^{35}$ Probably no judge ever came to the Bench with a clearer con-

2988 L. ed. 1958 (1944).

30325 U.S. 1, 67 (1945).

${ }^{31}$ HFS to S. Carr, Dec. 6, 1932, op. cit. supra note 26.

32 Fairman, Mr. Justice Miller AND the SUPREME COURT, 1862-1890 349-68, 370-71, 381, 429 (1939).

33 KING, op. cit. supra note 15 , at $180-81$.

34 Ibid. Howell Jackson was involved in the appointing process when a Senator; he helped Brown get appointed and Brown, in turn, when on the Court, helped Jackson.

35 For detailed accounts of Taft's activities in the appointing process and the criteria which he applied, see Murphy, In His Own Image: Mr. Chief Justice Taft and Supreme Court Appointments, 1961 SUP. С.. REv. 159, and Chief Justice Taft and the Lower Court Bureaucracy: A Study in the Politics of Judicial Administration, 24 J. Pourrics (Aug., 1962). In late 1962 or early 1963, Random House will publish a book-length study by Prof. Danelski on the appointment of Pierce Butler. 
ception of the "proper" role of the individual Justice within the Court or the "proper" role of the Court in the American political system. "Teamwork" was the Chief Justice's overriding value in intra-Court relations, and he saw the protection of property rights through the fifth and fourteenth amendments as the Court's principal task.

Since Harding had promised Sutherland the first place on the High Bench, Taft had little to do with the former Senator's appointment-except perhaps in a negative way in that both Taft and Sutherland had been candidates for the Chief Justiceship. The center chair had been Taft's avowed lifelong ambition, and Sutherland, so Harding said, was "crazy" for the office. ${ }^{36}$ Taft gave a broad hint about his alert interest in the appointing process when, after his own selection, he wrote a gracious letter to George Sutherland expressing the hope that Sutherland would soon join him on the Bench." Our views," the new Chief Justice noted, "are very much alike and it is important that they prevail." 37

When Justice Day retired, Taft, knowing that Harding was not committed to any candidate, began to work feverishly to find a suitable nominee. After failing to interest John W. Davis, the Chief Justice and Van Devanter decided that "Pierce Butler is our man." 38 Taft then opened an intense campaign to bring off the nomination. He called on the President and wrote him several letters lavishly praising Butler and criticizing other candidates. The Chief Justice also carried on a lengthy correspondence with Butler, giving him news on events in Washington and plying him with advice on how most effectively to advance his cause. Taft's suggestions included not only the best way for Butler to deploy his political assets but also how to exploit his religious assets as well. The Chief Justice realized that Harding wanted to appoint a Catholic (Justice McKenna was expected to retire soon) and also knew that Archbishop Hayes of New York was pushing Federal Circuit Judge Martin Manton. To counter this activity, Taft urged Butler to line up the Catholic hierarchy in the midwest. Butler protested that he abhorred the thought of involving clergymen in politics, but did supply the names of one cardinal, two archbishops, and three bishops, plus the bishops in the archdiocese of St. Paul, with whom Harding might consult.

After Harding nominated Butler, the Chief Justice switched his attention to the Senate and once again gave Butler detailed advice on which Senators were important and how they might be approached. Taft talked with his own friends on Capitol Hill and arranged a quick judiciary committee meeting to approve the nomination.

36 Taft's old friend and former Press Secretary, Gus Karger, told Taft this after a conversation with the President. Karger to WHT, May 25, 1921, op. cit. supra note 6.

37 WHT to Sutherland, July 2, 1921, the Sutherland papers, on file in the Library of Congress.

38 WHT to Van Devanter, Oct. 27, 1922, op. cit. supra note 6. 
When Pitney retired-with an assist from Taft in getting special legislation through Congress allowing full pay, despite the fact that Pitney had not yet reached the statutory retirement age-the Chief Justice once again plunged into the appointing maelstrom. Several candidates with impressive reputations were being considered for this vacancy, and the Chief Justice consulted with a number of people, including the President, the Attorney General, and the Chairman of the Finance Committee of the Republican National Committee. For Harding's benefit, Taft gave a run down on each of the people under consideration. He conceded that Judge Cuthbert Pound of the New York Court of Appeals "has some ability and experience," but had shown a preference for dissent over "teamwork" and "solidarity." Judge Frederick Crane, a colleague of Pound, was.a popular man. Although not a lawyer of "the greatest ability ... he would probably be preferable to Pound." Taft dismissed Chief Justice Robert Von Moschzisker of Pennsylvania as an accident-in Pennsylvania the chief justiceship rotated according to seniority, and the judges ahead of Von Moschzisker had died rather promptly. "He is a politician more than a judge." 39 (With his brother Taft was more candid: Von Moschzisker took too broad a view of the police power apd state control over the uses of private property. $)^{40}$

Cardozo, Taft continued in his letter to Harding, "is the best judge in New York. ... [He] is a Jew and a Democrat. I don't think he would always side with Brandeis, but he is what they call a progressive judge." Learned Hand was described as "an able judge and a hard worker. I appointed him ... but he turned out to be a wild Roosevelt man [in 1912] and a Progressive, and though on the Bench, he went into the campaign. If promoted to our Bench, he would almost certainly herd with Brandeis and be a dissenter. I think it would be risking too much to appoint him." 41

Taft had many kind words for U.S. District Judge William Grubb, a Yale classmate of Horace Taft; but the Chief Justice's highest praise was reserved for Judge Charles Hough of the United States Circuit Court of Appeals. Despite several personal pleas by Taft and his use of intermediaries, Harding refused to appoint Hough because he thought the judge too old. Later, in the course of a conversation with the Chief Justice, Harry Daugherty suggested the name of Edward T. Sanford, U.S. District Judge in Tennessee. Taft jumped at the suggestion and was soon strenuously supporting Sanford. The Chief Justice admitted to a friend that Sanford was not "the strongest man but I so much prefer him to Pound or Crane or the Chief Justice of Pennsylvania that I would now be glad to have him appointed."42 How much Har-

39 WHT to Warren G. Harding, Dec. 4, 1922, op. cit. supra note 6.

10 WHT to Henry W. Taft, Jan. 16, 1923, op. cit. supra note 6.

41 WHT to Warren G. Harding; Dec. 4, 1922, op. cit. supra note 6.

42 WHT to Henry W. Taft, Jan. 16, 1923, op. cit. supra note 6. 
ding's final decision was due to Taft, or to Daugherty, or to other political considerations will probably never be known, but once again the men whom Taft had opposed were kept off the bench and one of his candidates, although not his first choice, was appointed.

When McKenna retired-also with Taft's assistance, this time a positive suggestion to the Justice that he was too infirm to perform his duties in a satisfactory manner ${ }^{43}$ - the Chief Justice once more took part in choosing a colleague. He visited Coolidge and claimed to have "rather forced" the President to appoint Stone. ${ }^{44}$ Fourteen years later, when Stone heard of Taft's statement, he said he doubted that Taft had been influential with Coolidge or that Coolidge had needed anyone to recommend his Attorney General to him.45 Taft, however, had persisted in asserting responsibility for Stone's selection, even after he became convinced that he had made a serious error in the choice. 46

Stone, in turn, played a major part in Cardozo's nomination. Taking advantage of his close relationship with Hoover, Stone had introduced Cardozo to the President. As Stone recalled the incident, "I seized the opportunity to make the President acquainted with the kind of a judge he ought to appoint and prefaced the call by expatiating on that topic at some length." 47 On several later occasions Stone reminded Hoover of Cardozo's fitness, ${ }^{48}$ and strongly recommended him when Holmes retired. Hoover, however, wavered, fearing to offend the Senate by having three New York men (Stone and Hughes were also from New York) and two Jews (Brandeis was still on the bench) on the Court.

Stone then took a bold course of action:

I was apprehensive lest a selection should be made which would emphasize the Court's conservative tendencies, and feeling that they were already over-emphasized, I feared that great harm might result and that some sort of an explosion would occur not unlike that which actually took place after the decisions in the A.A.A. case and the Tipaldo Women's Wage case. In a conversation with President Hoover intended to emphasize both the importance of the appointment and Judge Cardozo's fitness I intimated to him that if he feared criticism because of the addition of a New York man to the Court when there were two other New Yorkers

43. Taft left a remarkable memorandum in his papers describing the background to and the actual discussion with McKenna about his resignation; see Murphy, In His Own Image: Mr. Chief Justice Taft and Supreme Court Appointments, 1961 Sup. CT. REv. 159.

it WHT to R. A. Taft, July 2, 1925, op. cit. supra note 6.

45 See Mason, at 184.

46 WHT to Horace Taft, June 8, 1928, op. cit. supra note 6.

47 HFS to G. Helman, May 29, 1939, op. cit. supra note 26.

48 HFS to B. Shein, Feb. 3, 1942, op. cit. supra note 26. As other possibilities Stone also mentioned Newton D. Baker and Learned Hand. HFS to R. Hale, Feb. 15, 1932, op. cit. supra note 26. 
already there, I would be willing to retire from the Court. Later, in conversation with Senator Wagner, who was then about to discuss the matter with President Hoover, I made the same suggestion. ${ }^{49}$

It is impossible to determine whether Stone was trying to put Hoover in a squeeze or was really tired of the frustrations of judicial work. 50 If the former explanation is correct, Stone was taking a dangerous gamble but he was also applying the strongest kind of pressure one can put on a close friend. Other men and forces were also at work in the appointment and Stone never claimed full-or even much-credit, though when the nomination was announced Frankfurter wired him: "The country is your debtor for your decisive help in achieving a great national good." 51

There undoubtedly have been many other instances of Justices working for or against the appointment of specific men. Van Devanter and Butler acted as intermediaries for the Attorney General in sounding out Charles Evans Hughes for the chief justiceship in 1930.52 In light of Attorney General Mitchell's long friendship with Pierce.Butler, it is not improbable that Butler was acting as more than a passive instrument of the Hoover Administration. Some judicial efforts have been succesşful, others may not have been. Some Justices, like Taft or Stone or perhaps Butler, have been in an excellent position to influence appointments; other Justices have not. But, since most mernbers of the Court have come to the bench only after extensive political experience, 53 the average Justice must have been aware of the informal as well as the formal channels through which influence could be exerted. Most important, it is quite clear that if a Justice wishes to enter the appointing process -and is able to do so-he can make ideology a prime factor in determining who will receive his support.

V.

That many Justices may be in a position to affect appointments does not mean that any particular Justice will always, often, or even ever have a voice

49 HFS to G. Helman, Nov. 30, 1939, op. cit. supra note 26.

so In 1929 Stone, disclaiming any altruism in offering to resign, said that he would not have been sorry to leave the Court because "I felt mine was a voice crying in the wilderness so far as the tendencies of the Court were concerned, and I had numerous opportunities to do worth while things." HFS to G. Helman, ibid. In 1929, less than three years before the Cardozo nomination, Stone had faced no less opposition on the Court-indeed Hughes and Roberts were less adamant in their conservatism than Taft and Sanford had been-but he had turned down several opportunities to leave the bench for lucrative private practice as well as offers to become Secretary of State and head of the National Law Reform Committee. These persistent refusals would not indicate an anxiousness to throw off the cares of the Court. On the other hand, Stone had ambitions to become Chief Justice and his name had been frequently mentioned as Taft's successor. Hughes' appointment to the center chair may well have dampened Stone's enthusiasm for judicial work.

s1 Feb. 15, 1932, op. cit. supra note 26. In the intervening years, Justice Frankfurter has changed his mind and no longer thinks Stone played a decisive role.

52 PusEY, op. cit. supra note 14, at 650-51.

53 Schmidhauser, supra note 5. 
in the selection of other members of the Court. Yor does it mean that those Justices who can exert influence will choose to do so. There are dangers in participating in the political processes, and a judge may reasonably conclude in a given situation that the risk is too great. He may also decide that, all political dangers aside, such participation would be contrary to standards of proper judicial conduct. A Justice who is ambitious for his policy must therefore consider alternative ways of influencing men who come to the Court.

If a Justice has not had any real part in selecting a colleague, he might still find it desirable not to deny having given assistance. Sanford, for example, was effusive in his thanks to Taft for helping him get promoted, $\leq 4$ and there is no recuid in the Taft-Sanford correspondence of the Chief Justice's informing Sanford that he had been a second choice. In addition, a Justice might wish to maintain close relations with potential appointees. In 1902, when Horace Lurton was hoping to be nominated to the Court, Justice Harlan wrote him:

Let me say confidentially that the President at the banquet [the previous evening] inquired about you. What was in his mind I do not know; nor did I deem it proper to inquire. I need only say that I said of you to him all that your warmest friend could have wished to be said.ss

Roosevelt did not nominate Lurton at this time, but Taft did seven years later.

Once an appointment has been made, the other members of the Court have to accept it and make the best of the situation. An older Justice might try to charm his new brother. A gracious letter of welcome may make the new Justice more disposed to trust a colleague's judgment, or at least more disposed to compromise without rancor. When W'iley Rutledge was appointed, Felix Frankfurter, who, along with Stone, had been widely reported as working for Learned Hand's promotion, Hrote the new Justice:

You are, I am sure, much too rise a man to pay any attention to gossip even when it is printed. And so I depart from a fixed rule of mine- which Lincoln's life has taught me-not to contradict paragraphs. I do so not because I think for a moment that the silly statement that I am 'opposed to' you for a place on this Court has found any lodgment in your mind but to emphasize it as a striking illustration of sheer invention parading as information. The fact of the matter is that the opposite of that baseless statement could much more plausibly be asserted.5

Three years earlier, when Frankfurter's nomination had been confirmed by the Senate, Hughes had immediately written a welcoming note:

Let me extend to you a warm welcome to collaboration in our workfor which you are so exceptionally qualified. We need you and I trust you will be able to take your seat at the opening of our next session on January

st. Sanford to WFT, Jan. 30, 1923, op. cit. supra note 6; muin of this letter is quoted in Murphy, supro note 43, at 183.

s: Harlan to Lurton, Dec. 16, 1902, the Lurton papers, on Ale in the Library of Congress. s6 Frankfurter to Rutledge, Nov. 6, 1942, op. cit. supra note 26. 
30th. If there is anything that I can do to aid in making your arrangements here, command me.

With kindest regards, and looking forward with the greatest of pleasure to the renewal, in this relation, of the association with you that I had when you were with the Department of Justice many years ago. . . . 57

Once on the Court, the freshman Justice, even if he has been a state or lower federal court judge, moves into a strange and shadowy world. An occasional helping hand-a word of advice about procedure and protocol, a warning about personal idiosyncrasies of colleagues, or the trustworthiness of counsel -can be helpful and appreciated. Particularly if a new Justice comes to Washington in mid-term, aid in securing clerical assistance and law clerks can be a means of establishing good will-with the new Justice as well as with his staff. 58

Comments on slip opinions provide another avenue of social access. A large ego seems to be a prerequisite to political success, and large egos bruise easily -though the exigencies of American politics probably sift out most of those people who have slow recuperative powers. In any event, a judicial opinion represents considerable labor, and it wpuld be a rare man who did not enjoy admiration of his intellectual offspring. Comments on slip opinions are frequently glowing in their praise. On the back of the draft of Stone's Darby opinion, Douglas wrote: "I heartily agree. This has the master's real touch!" Frankfurter added: "This is a grand plum pudding. There are so many luscious plums in it that it's invidious to select. But I especially rejoice over (1) the way you buried Hammer v. Dagenhart and (2) your definitive exposure of the empty hobgoblin of the 10th Amend. It's a superb job." On the back of Stone's dissent in Cloverleaf Butter Co. v. Patterson, Murphy said: "This seems to me the finest kind of writing and it is sound too." 59

After Hughes had finished his opinion in the Minnesota Rate Cases, 60 Justice Lamar sent him a note:

It is a great opinion and will stand as one of the greatest in our records. Your success ought to be compensation for your days and weeks and months of unceasing labor.... I congratulate you most sincerely and heartily on having written an opinion which not only sustains the particular rights of

57 Hughes to Frankfurter, Jan. 18, 1939, the Hughes papers, on file in the Library of Congress.

58 Stone suggested to Justice Byrnes that he hire Milton Handler of Columbia as a law clerk (HFS to Byrnes, Oct. 5, 1942, op. cit. supra note 26), and Van Devanter suggested to Hughes, when the latter became Chief Justice, that he retain Reynolds Robertson, Taft's law clerk. (Van Devanter to Hughes, Feb. 6, 1930, op. cit. supra note 57.) Hughes retained Robertson and also W. W. Mischler, Taft's longtime secretary.

59 The foregoing quotations are from slip opinions filed chronologically in the Stone papers, Cloverleaf Butter Co. v. Patterson, 315 U.S. 148 (1942); United States v. Darby, 312 U.S. 100 (1941).

60230 U.S. 352 (1913). 
the states and of the United States but, will be a landmark in the history of the Court.61

A week later Justices Day and Lurton wrote Mrs. Hughes: "Your husband has done a great work this day, the effects of which will be beneficially felt for generations to come. Congratulations." 62 Certainly such comments make for an easier exchange of views than remarks like McReynolds' about an opinion of which he did not approve: "This statement makes me sick."63

Mode of address is a minor matter, but it may be important to some Justices. Taft, for instance, always addressed his colleagues, even the new Court members, as "Judge"- - except Pierce Butler, whom he called by his first name. Stone was apt to speak to his senior colleagues by title, but to call others by their last name-a habit which struck several of the younger Justices as just a bit impolite. 64

Members of the Court should be sufficiently sophisticated to take flattery from colleagues no more seriously than do most Senators. Judges are usually mature, educated, and experienced men, long accustomed to recognizing and thwarting efforts to smooth-talk them into favors. 65 It would be a rare Justice who would succumb to flattery to the extent of changing his vote. Yet friendship and the social amenities can play an important auxiliary role in the judicial process. If friendship or a simply pleasant personal relationship is accompanied by true intellectual respect, a Justice may be more willing to reexamine his own views on a problem. Or he may at least be more willing to try to work out a compromise.

When Stone first came to the Court, he was, as Taft had thought, fundamentally a conservative. Within a very few years, however, Stone had joined Holmes and Brandeis in what the Chief Justice considered "radical" constitu-

61 Lamar to Hughes, June 3, 1913, op. cit. supra note 57.

62 Day to Mrs. Hughes, June 9, 1913, op. cit. supra note 57. There is a similar letter of the same date to Mrs. Hughes from Justice Lurton.

63 PUSEY, op. cit. supra note 14, at 671.

64 There are other weights which a Justice can throw on the social scale in dealing with new or old colleagues, though as in all aspects of his behavior he must be subtle and circumspect. Many people still treasure the respect and recognition signified by an honorary LL.D. and during most periods of Court history one or more members have had close connections with a major university. Of course, one Justice could not ever tell another that he had recommended him for an honorary degree, but there are more delicate ways of communicating this fact-if, indeed, anything at all need be communicated. This academic influence can also be used as a weapon against an opponent. Taft worked long and hard to get Yale to bestow an LL.D. on Van Devanter, writing laudatory letters to the President of the University and members of the Board of Trustees whom he knew personally. Yale conferred the degree in 1927. On the other hand, when a member of the Yale faculty wrote the Chief Justice asking advice about giving Brandeis an honorary degree, Taft apparently did not reply-at least there is no reply in the Taft papers. For an interesting account of the efforts of Yale to confer an LL.D. on Brandeis, see MASON, BrandeIs: A FreE MAN's LiFE 613-14 (1946).

6s Holmes, of course, once commented that "Judges are apt to be naif, simple-minded men"; and, he added, "they need something of Mephistopheles." Law and the Court (1913), reprinted in THE MIND AND FAITH OF JUSTICE Holmes 390 (Lerner ed. 1943). 
tutional opinions. In part this change reflected Stone's capacity for intellectual growth, but the warm and stimulating companionship of Holmes and to a lesser extent Brandeis may also have been a decisive factor. As Thomas Reed Powell, a long time confidant of Stone, commented, it was "respect and liking for Holmes and Brandeis that turned him from earlier attitudes." 66 On the other hand, Stone probably had little intellectual respect for Taft. This fact, coupled with McReynolds' bigoted attitude toward Brandeis as well as his continual carping at Stone's opinions, ${ }^{67}$ did little to keep the new Justice in the conservative camp.

Stone's change of viewpoint may be an unusual case. Probably more typical is that of the Justice who finds it easier to compromise with a colleague who has shown him respect and consideration than with an associate who has been coldly formal or even impolite. Holmes and Sutherland had very different views of the judicial function, 68 but they were able to work together in making mutual accommodations much more easily than, for example, Brandeis and McReynolds. Conversely, lack of rapport can severely limit opportunities for influencing the Court's work. The relations between McReynolds and Clarke were almost as strained as between McReynolds and Brandeis, and as Clarke once told Taft, "I never deign-or dare-" to make suggestions to McReynolds, J., as to his opinions." 69

\section{VI.}

When nine-or five-men try to agree on the precise wording of a document embodying an important statement of public policy, there is inevitably a great deal of bargaining. In the judicial process most of this bargaining may be tacit; 70 but, whether expressed or not, compromise and mutual accommodation are necessary for agreement. Thus how to bargain wisely-not necessarily sharply-is a prime consideration of a Justice who is anxious to see his policy adopted by the Court. If he is writing the opinion of the Court, a Justice may look on his role as that of a broker, adjusting the interests of his

${ }^{66} \mathrm{MASON}_{s}$ at 254.

67 Few of Stone's early opinions escaped criticism from McReynolds, criticism of a kind which can best be described as "picky." In McReynolds' defense, however, it should be said that he believed-though he was not always able to translate his belief into practice-that a judicial opinion should say no more than absolutely necessary to decide a specific case. "When a judge fully appreciates that every unnecessary word in an opinion hurts it, he may be relied upon to write with good effect. But when vanity, or an itch to throw off new and striking phrases and shine in the books, troubles him, his outgivings are apt to be noxious." McReynolds to Judge Hollzer, Aug. 31, 1933, the McReynolds papers on file in the Alderman Library, the University of Virginia. McReynolds felt (quite correctly, see text accompanying note 102 infra) that Stone often put more into his opinions than the cases demanded.

68 See Paschal, Mr. Justice Sutherland 116 (1951).

69 Clarke to WHT, undated memorandum c. 1922, op. cit. supra note 6.

70 For an excellent discussion of the wide possibilities of "tacit" bargaining, see SchrLLING, op. cit. supra note 1 . 
associates (as well as of himself). If the Justice is not writing for the Court, and if the case is significant for his policy, he must put effective pressure on the opinion writer; how much pressure is sufficient to be "effective" and how much will overshoot the mark and alienate the opinion writer are crucial and delicate questions. In any situation, a Justice has to be willing often to settle for less than he wants if he is to get anything at all. As Brandeis once remarked the "great difficulty of all group action, of course, is when and what concession to make."71

To bargain effectively, one must have something to trade and also a sanction to apply if the offer is rejected or if there is a renege on the bargain. The personal honor of the Justices minimizes the possibility of a renege in the usual sense of the term, though under existing Supreme Court practice a Justice is free to change his vote up to the minute the decision is announced in the courtroom.

The most important items a Justice has to offer are his vote and his concurrence in an opinion. Conversely, the threat of a dissenting or concurring opinion is the most frequently used sanction. Except in five-four decisions, the effectiveness of this sanction depends in large measure on a Justice's intellectual vigor and literary skill. The threat of a dissenting opinion by one Justice can be a powerful force, while a similar threat from another may be hardly worth considering. All intra-Court bargaining takes place with these facts clearly understood, although they may not always be as clearly stated as the following memorandum which Stone sent Frankfurter:72

If you wish to write, placing the case on the ground which I think tenable and desirable, I shall cheerfully join you. If not, I will add a few observations for myself.

Only slightly less direct was the note, attached to a draft of a concurring opinion, which Stone sent Roberts:

I doubt if we are very far apart in the Cantwell case, but in order that you might get exactly my views, I have written them out and enclosed them herewith.

If you feel that you could agree with me, I think you would find no difficulty in making some changes in your opinion which would make it unnecessary for me to say anything. 73

Usually suggestions for change are simply scribbled on the margins of slip opinions or, if the notations are extensive, on a separate memorandum. The threat to pull out normally need not be expressed.

Changing a vote is probably a less common phenomenon than switching allegiance among concurring factions. The Taft and Stone papers, however, contain a number of examples of Justices changing their votes. Typically the

71 BiCKel, UNPUBlished OPINIONS OF MR. JUSTICE BRANDEIS 18 (1957).

72 HFS to Frankfurter, Jan. 20, 1941, op. cit. supra note 26.

73 HFS to Roberts, May 1, 1940, op. cit. supra note 26. 
issue has been one in which the Justice did not perceive an important public policy question. Stone, for instance, said he made it a rule never to file a dissent on a question of private law, and he, like Holmes and Brandeis, frequently suppressed public law dissents in the belief that overuse cheapened their value. 74

The danger of a strong dissent may create a bargaining situation. Desiring as large a majority as possible, the opinion writer may be willing to dilute his views to the point where a minority Justice could quietly acquiesce, knowing that dissent might cause the majority to strengthen the prevailing opinion or perhaps draw attention to and so emphasize what the Justice thinks is a serious error. "Silence under such circumstances," Alexander Bickel has pointed out, "is a gamble. ... The risk is that if the birth is successful, silence will handicap one's future opposition. For one is then chargeable with parenthood. ... Brandeis was to face the dilemma more than once. Instinct, a craftsman's inarticulable feel, which must largely govern action in such a matter, dictated now one choice, now the other."7s As Justice Johnson once wrote: "the report of the case of Sturges $v$. Crowninshield needs also some explanation. The Court was, in that case, greatly divided in their views of the doctrine, and the judgment partakes as much of a compromise as of a legal adjudication. The minority thought it better to yield something than risk the whole."76

A Justice may apply sanctions which are stronger-and consequently more dangerous-than a dissenting or concurring opinion. In 1893, Justice Field took what might be termed extreme measures against Justice Gray. After reading Field's dissent in Fong Yue Ting v. United States, 77 Gray changed a sentence in his opinion for the majority. Feeling this took some of the sting out of his dissent, Field wrote Chief Justice Fuller that if Gray did not restore the sentence as originally written, he-Field-would add a footnote to his opinion explaining that Gray had corrected his error. Gray consulted with the Chief Justice and backed down, leaving the sentence as originally written.78

McReynolds expressed his displeasure over Justice Clarke's votes and opinions in an even more virulent fashion. When Attorney General, McReynolds had been instrumental in getting Clarke appointed to the district bench, and when Clarke was promoted to the Supreme Court McReynolds thought the new Justice should follow his benefactor's ultra-conservative constitutional philosophy. Clarke's voting behavior was erratic, but he tended to side more

${ }^{74}$ See HFS to Karl Llewellyn, quoted in MASON, at 388. “. . . if I should write in every case where I don't agree with some of the views expressed, you and all my other friends would stop reading them."

75 BICKEL, op. cit. supra note 71, at 30.

76 Ogden v. Saunders, 12 Wheat. 213, 272-73 (1827).

77149 U.S. 698 (1893).

${ }^{78} \mathrm{KnNG}$, op. cit. supra note 15 , at 185-86. 
with Holmes and Brandeis than with McReynolds on constitutional cases. As a result, McReynolds cut off all pleasant social relations with Clarke, meting out only curt sarcasm to his former protégé.79

Similarly, but in one swift blow, Justice Jackson lashed out at Justice Black in 1946. Roosevelt had promised-or led Jackson to think that he had promised-to promote Jackson to the chief justiceship when Stone stepped down, but Stone outlived Roosevelt by eleven months. When Stone died, Jackson was at Nuremberg finishing his work as chief American prosecutor of the Nazi war criminals, and he heard rumors that Black and his friends were feverishly lobbying against his promotion. Infuriated, Jackson cabled a long letter to the chairmen of the House and Senate judiciary committees, charging that Black had made "public threats to the President" to resign if Jackson were appointed Chief Justice. Jackson then offered a detailed explanation of the feud between himself and Black, accusing Black of "bullying" tactics and of dealings of questionable propriety in sitting in a case argued by a former law partner. 80

Like massive retaliation, the threat of airing disputes in public is effective to the extent that it is never actually applied. Its use may embarrass one's adversary, but even its openly threatened use may enrage him to the point of total alienation as far as future consultation or compromise is concerned. More important-since, if the Justice employing such a sanction is rational, he would not make the threat unless relations with the target Justice had already reached a hopeless point-such public sanctions damage the Court's prestige and so weaken its institutional power and thereby the Justice's ability to use that power for his own ends.81 McReynolds' tactics were only slightly less dangerous in that his shabby treatment of his brethren did become known outside the Court-though not with a dramatic effect comparable to that achieved by Jackson in his Nuremberg cable. On the other hand, McReyn-olds' tactics may have been the most successful of the three since Clarke resigned in 1922.82 Clarke claimed to be bored with "the trifling character of

79 See Murphy, supra note 43, at 165-66.

80 For an account sympathetic to Jackson, read GERHART, op. cit. supra note 4, ch. 15 ; for an account sympathetic to Black, read FrANK, MR. JUSTICE BLACK: THE MAN AND HIS OPINIONS ch. 7 (1948).

81 It is conceivable of course that.in a given period a Justice may become so despairing of "educating" his colleagues that, at least in the short run, destroying judicial power seems a rational strategy. Long range considerations aside, this would be a difficult feat to perform without in the process ruining one's own reputation and so also damaging one's cause. I have seen no hint of evidence that any Justice in any period of Court history tried to carry out such a strategy, though certainly the thought must have occurred to more than one judge.

82 Justice Jackson once remarked in private that the unpleasantness in personal relations on the Court during the mid-forties made him seriously consider resigning. McReynolds treated Brandeis with even greater disdain than he did Clarke, but in his own fashion Brandeis was as tough as McReynolds and would not be budged by such tactics. 
judicial work,"83 but Taft, who had been an appalled witness to the feud, felt sure that the real reason was McReynolds. ${ }^{84}$.

VII.

Goldman v. United States 85 provides an example of several different kinds of intra-Court bargaining. Under review was a conviction of three lawyers for conspiring to violate the Bankruptcy Act. Federal agents, with the cooperation of the building superintendent, had entered the office of one of the defendants and installed a listening device. The apparatus failed to work, but the agents, who had occupied the adjoining office, utilized a detectaphonean instrument which can amplify the sound of voices talking on the other side of a wall-and transcribed several incriminating conversations among the defendants. Justice Roberts, speaking for a majority composed of himself, Black, Douglas, Rutledge, and Reed, affirmed the conviction, holding that use of the detectaphone did not violate the Federal Communications Act, nor, under the doctrine of Olmstead $v$. United States, 86 the famous wiretapping case of 1928, did such use contravene the fourth amendment. Roberts also stated that whatever trespass federal agents had committed in installing the listening device did not make inadmissible evidence obtained through the detectaphone.

At the conference in early February, 1942, Stone, Frankfurter, and Murphy wanted to overrule Olmstead and reverse the convictions. Justice Jackson noted only that he did not think he could take part in the decision. As senior majority judge, Roberts assigned himself the opinion of the Court, and Stone undertook to write a brief dissent. Frankfurter made some suggestions for changes in Stone's opinion and by February 27, after these had been incorporated, the draft read simply:

Had a majority of the Court been willing at this time to overrule the Olmstead case, we would have been happy to join them. But as they have declined to do so, and as we think this case is indistinguishable in principle from Olmstead's, we have no occasion to repeat here the dissenting views [of Holmes, Brandeis, and Butler] in that case with which we agree.

Both courts below found that the trespass by the Government officers in locating the dictaphone did not aid materially in the use of the detectaphone. Hence it is unnecessary to consider whether the use of the detectaphone, if aided by the trespass, would constitute a violation of the Fourth Amendment. The Government did not deny that it would, and we explicitly dissociate ourselves from the declaration in the opinion [of the Court] that it would not. 87

83 Clarke to WHT, Sept. 12, 1922, op. cit. supra note 6.

84 WHT to Warren G. Harding, Sept. 5, 1922, op. cit. supra note 6.

85316 U.S. 129 (1942).

86277 U.S. 438 (1928).

87 Draft opinion, op. cit. supra note 26. Several minor changes were made prior to publication. "Would" was changed to "should"; "Olmstead" was not italicized; and "case" was begun with a capital letter. 
When members of the majority read the second paragraph of Stone's opinion, they agreed to modify their own statement regarding the trespass and substantially adopted Stone's statement: "Both courts below have found that the trespass did not aid materially in the use of the detectaphone. Since we accept these concurrent findings, we need not consider a contention based on a denial of their verity." 88 Having achieved this minor victory, Stone dropped the second paragraph of his opinion.

Meanwhile, Murphy was balking at Stone's refusal to spell out in detail the minority's views. On March 5, Frankfurter tried to placate him:

You have heard my views expressed in Conference, and I am afraid somewhat fiercely, on wire-tapping, and you must, therefore, know that I am as uncompromising on that subject as you are, feeling as you do that the issue goes to the very essence of a civilized society. Like you, therefore, I will not yield an inch on my convictions and would accede to no conpromising expression of them.

But I do not see that any "compromise" is involved in the way in which the C. J. has formulated dissent from the majority opinion. Of course each man's phrasing has its own distinctive quality. but so far as the substance of the matter goes, I certainly could not dream of improving on what Brandeis and Holmes said in the Olmstead case. And so it seems to me that an unequivocal announcement that we would overrule the Olmstead case and adopt as our own the views expressed by the dissenters in that case, is an unswerving and unqualified adoption of these views and a reaffirmation of them. And to do it in the way in which the Chief Justice proposes has for me the quality of Doric eloquence. Simplicity and austerity are sometimes the most emphatic way of conveying an idea to the world. 89

In closing this letter, Frankfurter added a plea for solidarity:

For the three of us to speak in different language would imply a difference of opinion amongst us. That would attenuate the moral strength of our position. I hope very much, therefore, that it will commend itself to you to have the three of us speak with one voice and in the way in which the C. J. has proposed.

Murphy, however, was unconvinced and proceeded to write a long and eloquent dissent, asserting that government officers had committed a palpable invasion of defendants' privacy in violation of explicit prohibitions of the fourth amendment. In his opinion, he referred to the federal agents as "overzealous officials," and castigated their action as "debasing to government."

On April 6, after Murphy's dissent was circulated, Justice Jackson, who had been Attorney General when the Goldman prosecution was conducted, sent a memorandum to all members of the Court. Jackson said that in light of

88316 U.S. 129, 135 (1942).

89 Frankfurter to Murphy, March 5, 1942, op. cit. supra note 26. 
Murphy's remarks he felt it necessary to file an opinion to explain his own disqualification in the case:

As notation of my disqualification without more would create uncertain implications as to my responsibility for the questionable conduct of the investigation, it is desirable to state the precise facts which lead to my non-participation.

Thirteen days after I was commissioned as Attorney General of the United States this indictment was found. While the prosecution was determined upon and prepared and the detectaphone recordings in question were made prior to my entrance into office and under rules, regulations, and practices of the Attorney General that I found in force, the prosecution was continued under my official responsibility. Under these circumstances it seemed appropriate to refrain from judicial action in the case.

Since he had been the Attorney General who preceded Jackson and since, therefore, the action which he was so bitterly criticizing had been conducted under his own official responsibility-though probably without his personal knowledge-Murphy was put in a squeeze. The squeeze was made even tighter because, although the matter is ultimately one for the judgment of each Justice, there would be doubt-and Jackson's opinion would draw attention to the doubt - that a former Attorney General should hear a case on the bench which was invesigated under his auspices. The same day as Jackson circulated his opinion, Murphy contacted him and indicated a willingness to reconsider his remarks. ${ }^{90}$ Jackson immediately seized the opportunity to seal a bargain. In a letter which began "My dear Frank," he offered a full statement of his feelings:

This case presents a new question of law on which difference of opinion is to be expected and upon which it is conceivable that one's attitude as a prosecutor and as a judge might differ. However, the Department of Justice under several Attornies General has assumed the law to be as the Court now holds it to be. Even so, any Attorney General was empowered to impose further limitations on investigative methods if he thought good morals or good government required it. None of us did so....

But any discomfort of my own is small compared with the position of those who served under both of us and who looked to us-not as much as they should have, perhaps-for guidance and supervision.... My grievance is only academic compared to the gravity of putting words such as I have quoted ["overzealous officials," action "debasing to government"] into the mouth of every criminal lawyer in the United States to be hurled at the Government as quotations from a former Attorney General and a present Justice, when it attempts to use evidence the Court now holds to be its legal right. ...91

90 So Jackson noted in his letter to Murphy of April 6, 1942, op. cit. supra note 26. 91 lbid. 
In his next to the last paragraph, Jackson further tightened the squeeze on Murphy by withdrawing his opinion:

Now that you know how I feel in the matter, I shall leave the result to your own good judgment. Whatever you do, I think the interests of the Court would not be served by carrying the matter to the public. I commit myself not to do that in order to leave you free of any pressures in the matter except those of your own strong sense of justice.

As the final turn of the screw, Jackson noted in his closing sentence: "I am sending a copy of this to the Chief Justice and to our associates so that they may know the way the matter stands."

Murphy was left with no real choice. He might have been able to answer Jackson's argument about how his remarks would reflect on Justice Department officials, past or future; but Jackson's withdrawal of his own opinion and his announcement of this fact to the Court had put Murphy in a position where he had to compromise. In effect, Jackson had opened the door to negotiation and then had shoved Murphy through it. Murphy's published opinion excused the Justice Department from any deliberate wrongdoing:

On the basis of the narrow, literal construction of the search and seizure clause of the Fourth Amendment adopted in Olmstead v. United States.... Government officials could well believe that activities of the character here involved did not contravene the Constitutional mandate. But for my part, I think that the Olmstead case was wrong.92

\section{VIII.}

The style of bargaining is of crucial importance. Negotiations, to achieve maximum long and short range effectiveness, must be carried on with tender regard for the feelings of all concerned. Stone, for example, wrote Douglas about the latter's opinion in a 1942 term case:

I have gone over your opinion in this case with some care, and I congratulate you on your lucid and penetrating analysis and the great thoroughness with which you have done a difficult job. If Justice Brandeis could read it he would be proud of his successor. ${ }^{93}$

Stone then quietly added to these gallantries a single spaced typewritten page of suggestions for revision. Similarly, when a Justice has won a fight, he may be well advised to offer the olive branch to the loser, for today's opponent may be tomorrow's ally. After their failure to agree in the first Flag Salute Case, Frankfurter wrote Stone a gentle note: "Though we read the scales differently in weighting these 'imponderables.' I cannot but feel confident that our scales are the same. In any event our ways do not part and we care no differently for the only things that give dignity to man-the things of the spirit." 94

92316 U.S. 129. 140-41 (1942).

93 HFS to Douglas, Feb. 20,1943, op. cit. supra note 26; the case in question was Group of Institutional Investors v. Chicago, M., \& St. Pac. R.R., 318 U.S. 523 (1943).

94 Frankfurter to HFS, op. cit. supra note 26, dated only "Friday." From its place in the file, I judge the year to be 1940 . 
The Chief Jústice has added capital on which to trade. He can use the opinion assigning power 95 to try to hold wavering members of his majority and to try to capture new votes. When with the majority he can, for example, assign the opinion to the most moderate member, hoping his mild statement of the doctrine might prevent defections or even gain adherents. The Chief may even assign the opinion to a wavering Justice, hoping that this commitment-if not further reflection and research-would strengthen the Justice's resolve and perhaps sway the minority. Alternately, the Chief Justice may use the opinion assigning power to strengthen his coalition within the Court. He can assign the opinions in interesting and important cases to those Justices who tend to vote with him, leaving the dregs for those who vote against him on issues he thinks important. This authority may also be used as a means of encouraging an elderly or failing colleague to retire. Chief Justice Fuller withheld opinions from old Justice Field to help nudge him off the bench, and Taft tried the same tactic with McKenna.96

The advantages of the opinion assigning power are augmented by the fact that the Chief Justice votes last in conference. Thus, before he finally commits himself, he knows where each Justice stands-at least for the present-and which side will most probably win. 97 If his own views are going to be in the minority, the Chief Justice can vote with the majority and retain the opinion assigning authority. He may keep the opinion himself-as apparently John Marshall often did-and so do a minimum of damage to his own deeply felt values. Or the Chief may assign the opinion to the majority Justice whose views are closest to his own. It is worth noting in this regard that during his first nine terms as Chief Justice (1930-38), Hughes officially registered only 23 dissents in 1,382 cases decided by full opinion. 98

As has already been pointed out, the Chief Justice's advantages here are not necessarily decisive. All other factors aside for the moment, the advantage $v i s-\grave{a}$-vis other Justices of voting last varies with the seniority of the individual Justice. Remembering the Chief Justice's voting record and just having heard him express tentative views on the case at bar, the senior Associate Justice has

9s Danelski, The Assignment of the Court's Opinion by the Chief Justice (unpublished paper presented to the 1960 Midwest Conference of Political Scientists), has a valuable analysis of this facet of judicial decision-making.

96 For examples of this tactic by Fuller, see KING, op. cit. supra note 15, at 223-24. In numerous letters during 1922-24 Taft complained that he was assigning fewer and fewerand simpler and simpler-cases to McKenna, and pointed out this fact to the Justice when the two men discussed the necessity of McKenna's resignation.

97 Since the Justices are technically free to switch their votes up to the time the decision is actually announced, last minute changes in decisions are always theoretically possible.

98 This almost mystical record of agreement with shifting majorities does not mean, of course, that Hughes always voted with the majority at conference. He may often have simply decided not to make public his disagreement. Statistics of this sort will vary slightly depending on the method of classification. I have explained my peculiar approach to this problem of taxonomy in CONGRESS AND THE COURT 251 note (1962). 
an accurate idea about the Chief Justice's true feelings. Thus, since seven Justices have voted before him, he is also in a good position to adopt deceptive strategies similar to those open to the Chief Justice. He may vote with the majority and hope that the Chief Justice (if he, too, is with the majority) will pick him to write the Court's opinion, or that the Chief Justice will dissent and leave him the authority of assigning the opinion writer. To a lesser extent, similar opportunities are open to the other Justices.

There are pressures other than votes or threats of separate opinions. Several Justices have had close relations with law school professors and can sometimes reward or punish colleagues through articles in professional journals. A resounding series of critical law review articles can be a factor in persuading a Justice-providing he is unaware of the inspiration behind the criticism-to re-examine his position. On the other hand, a highly laudatory law review reaction might convince a self-doubting Justice that he was on the right track or give courage to a minority Justice who has begun to wonder if the game is worth the candle. Taft was sure that Brandeis had a "claque" of law school professors ready to do his bidding, 99 and similar charges have been made about other Justices.

A Justice could conceivably exert pressure on a wavering colleague through the influence of an off-the-bench friend. While this particular tactic is contrary to accepted standards of judicial behavior, it has been used on at least one occasion. When the Dred Scott case was under consideration, Justice Catron wrote President-Elect Buchanan not only informing him of the progress of the Court's deliberations, but also asking that he prod Grier into joining Chief Justice Taney's faction. "I want Grier speeded," Catron told Buchanan. Buchanan obliged, and for whatever reason, or combination of reasons, Grier put aside his earlier doubts and voted with the Chief Justice and Catron.100

IX.

Effective bargaining requires a peculiar set of skills plus a fine capacity for understanding what will appeal to the various people who have to be convinced. In some situations a direct, bluntly uncompromising approach may turn out to be the wisest course over the long haul. For years Field bludgeoned his colleagues with fiery, righteous arguments about the laissez-faire implications of the fourteenth amendment. Men like Miller and Waite stoutly resisted, but Field outlived them, and with his ideological allies on and off the bench eventually created a climate of judicial opinion which put Herbert Spencer into the Constitution. In a similar fashion, but with a more delayed effect, Harlan left a series of ringing dissents in race cases which would gnaw at the conscience of the Court for three-quarters of a century.

99 WHT to W. L. Phelps, May 30, 1927, op. cit. supra note 6.

100 For a full account of the intra-Court maneuverings in the Dred Scott case, 19 How. 393 (1857). see SWISHER, Roger B. TANeY 495-502 (1935). 
In other situations, indirect strategy is more effective. Like any good political or military leader, a judge may find it advantageous to mask his ultimate goals. Bargaining situations usually confer a psychological advantage on the party who is able to confuse his opponents as to which aspects of his arguments are propaganda, and which are rock-bottom minimum. This ability to dissemble, Tugwell claims, ${ }^{101}$ was one of the keys to Franklin Roosevelt's success. Such a talent would seem to be invaluable in the judicial process where the bargaining is so often unspoken.

Moreover, if the Justices do not perceive where a judge is leading them, they are less likely to be able to stop the march. Stone frequently tried to change existing constitutional law, but he usually did so with caution, masking both his tactics and aims. He preferred to plant the seeds of a new doctrine in the dicta of a majority opinion rather than announce his views in an eloquent but impotent dissent. As one of his law clerks recalled, Stone was often "like a squirrel storing nuts to be pulled out at some later time. And there was mischief as well as godliness in his delight when his ruse was undetected and the chestnuts safely stored away." 102

Stone would dissent when he thought the issue important and could see no hope for compromise. At least when he was an Associate Justice, his bargaining power was probably enhanced by his ability to write slashing opinionsthough perhaps he overdid it in his $A A A$ dissent, ${ }^{103}$ which Roberts felt so personally stinging that he asked first Hughes then Brandeis to intercede to get some of the wording toned down. ${ }^{104}$ But, when faced with majority opposition, Stone frequently rolled with the punch. One of his pet dislikes in American constitutional law was the doctrine of reciprocal tax immunity, which exempted not only state and federal office holders from taxation by the other government, but which also allowed firms doing business with government agencies to escape their full share of taxation. ${ }^{105}$ Stone's approach was to work slowly, gradually undermining the immunity doctrine rather than openly repudiating it. In 1931, for instance, he wrote an opinion for a six judge majority sustaining the constitutionality of a New York tax on corporate in-

\section{0! Tugwell, The Democratic Roosevelt 11, 35-36, 97 (1957).}

102 Undated memorandum by Herbert Wechsler, Law Clerk File, op. cit. supra note 26. Taft was not unaware of Stone's propensity to add dicta, though he did not understand what Stone was trying to do. As the Chief Justice told his son: Stone "has great difficulty in getting his opinions through [the Court], because he is quite disposed to be discursive and to write opinions as if he were writing an editorial or comment for a legal law journal. ... Without impeaching at all his good faith in matters of that sort, we find we have to watch closely the language he uses." WHT to C. P. Taft, II, May 12, 1929, op. cit. supra note 6. As he gained experience, Stone apparently became more adroit at his "planting" game.

103297 U.S. 1, 78 (1936).

104 Mason, 408, note.

105 For a systematic exposition of Stone's philosophy on this issue, see KonerskY, CHIEF Justice Stone AND THE SUPreme COURT ch. 1 (1945). 
comes, 106 even though part of the income involved in the litigation had been derived from a copyright granted by the federal government. In 1929 the Macallen case 107 had strictly applied the immunity doctrine to hold invalid a state tax which did not exempt income obtained from federal securities. In light of the firmness of the Macallen opinion it would have seemed that the Court had either to reverse itself or declare unconstitutional the New York tax. But Stone iook neither alternative. Instead, he adroitly used dicta from the Macallen opinion to distinguish the two cases.

Thomas Reed Powell was pleased by the decision but disappointed by the deviousness of the reasoning, and he wrote an article lampooning the opinion. ${ }^{108}$ Stone chuckled over Powell's satire and sent him a letter explaining his strategy:

I should have preferred to have written your opinion than the one which will actually appear in the books. Had I done so, I should have been in a minority of two or three, instead of a majority of six. Someone else would have written the opinion and. I fear, would have said some approving words (which I have carefully avoided in this and other cases) of doctrine, about which the less said the better, unless it be flatly disapproved. In other words, you will see that I proceed upon the theory, which I am willing to admit may be a mistaken one, that the large objective should be kept constantly in mind and reached by whatever road is open, provided only that untenable distinctions are not taken, and that 1 am not, in the process, committed incidentally to the doctrine of which I disapprove or which would hinder the Court's coming out ultimately in the right place. All of this proves that the university professor is the only free man who can develop legal doctrine in his own way and travel the road he chooses in accounting for his conclusions. ${ }^{109}$

Stone's preference for indirect strategy made a striking contrast with Justice Black's early efforts to batter down precedents which he thought wrongly decided. This difference in approach undoubtedly increased the personal strain between the two judges.110 a strain which would soon smother similar outlooks on many basic pulicy questions. But Black may also have been following a well thought out strategy. Irving Brant conceded that some of Black's early opinions appeared quite brash, but added that Black was fond of telling the story "about a Senator who said that, when he wanted to ac-

${ }^{106}$ Educational Films Corp. v. Ward, 282 U.S. 379 (1931).

107 Macallen Co. v. Massachusetts. 279 U.S. 620 (1929).

108 Powell, An Imaginary Judicial Opinion, 44 HaRv. L. REv. 889 (1931).

109 HFS to Powell, Jan. 26, 1931 ; most of Stone's letter is reprinted in MASON, 308.

110 Id. at 472-76. Mason sums up: "Black put Stone in the awkward position of defending precedents at which he had been whittling away for years with a view to their ultimate demise. Originally forced on him by the Old Guard, this method had now become endemic, an unchanging essential of the judicial process, linked by him to judicial self-restraint." Id. at 476. 
complish something, he introduced two bills, the one he wanted passed, and the other that made the first one seem conservative." 111 Under the circumstances, the surviving members of the old Court might well have been more disposed to allow government regulations of business in order to head off such radical schemes as Black's proposal to reverse some sixty years of constitutional law by putting corporations outside the protection of the fifth and fourteenth amendments. 112

Another means a Justice may use to increase his bargaining power is to build up good will by frequently acceding to the majority-and letting the majority know that, although acquiescence goes against his better judgment, all doubts are being stifled for the sake of harmony. As Pierce Butler once wrote on the back of one of Stone's slip opinions:

I voted to reverse. While this sustains your conclusion to affirm, I still think reversal would be better. But I shall in silence acquiesce. Dissents seldom aid in the right development or statement of the law. They often do harm. For myself I say: "Lead us not into temptation."113

Sutherland, too, let Stone know his real feelings. In 1930 he commented: "I was inclined the other way, but I think no one agreed with me. I, therefore, yield my not very positive views to those of the majority."114 In 1932 he told Stone: "I voted the other way, but I have acquiesced in other outrages and probably shall in this. Shall let you know Saturday, though I should like more time to forget."115 Three years later, he noted on the back of the Alaska Packers opinion: "Probably bad-but only a small baby. Let it go."116 As handed down, all three decisions were unanimous. Hughes, too, would forego dissenting. As he commented on a 1939 slip opinion: "I choke a little at swallowing your analysis, still I do not think it would serve any useful purpose to expose my views." 117 It is also worth noting again here that Hughes, in his first nine terms as Chief Justice (1930-38), officially registered only 23 dissenting votes out of 1,382 full opinion cases.

If such concessions as these are made on issues which a Justice does not think important-or on which he would have been in a small minority anyway -he has lost very little and may have put himself in an excellent position to

111 Brant, A Man Who Honors Liberalism, PM, April 3, 1945, p. 2.

112 Connecticut General Life Ins. Co. v. Johnson, 303 U.S. 77 (1938).

113 Slip opinion, op. cit. supra note 26; the case was The Malcomb Baxter, Jr., 277 U.S. 323 (1928).

114 Slip opinion, op. cit. supra note 26; Broad River Power Co. v. South Carolina, 282 U.S. 187 (1930).

115 Slip opinion, op. cit. supra note 26; Lamb v. Schmidt, 285 U.S. 222 (1932).

116 Slip opinion, op. cit. supra note 26; Alaska Packers Ass'n v. Industrial Accident Comm'n, 294 U.S. 532 (1935).

117 Quoted in Danelski, The Influence of the Chief Justice in the Decisional Process, in MURPHY \& PRITCHETT, op. cit. supra note 2, at 506. 
win reluctant votes from colleagues on other issues. Certiorari voting supplies an opportunity for such tactics.118 The Court's rules require a vote of four Justices to bring up a case, but where one or two members feel strongly about granting certiorari in a case, another Justice-providing the final decision in the litigation is not likely to affect his cause detrimentally-can capitalize on the situation by graciously saying something to the effect that he is willing to defer to the judgment of the minority.

A very different means of increasing bargaining power is for a Justice to take a stand on one or more questions from which he cannot retreat without serious loss of face. In game theory parlance, a Justice may narrow his discretion to broaden his power. 119 One of the more important potential advantages of this tactic is that it helps insulate a Justice from suggestions of compromise which, in a particular situation though hardly as a general rule, he may wish to avoid. Furthermore, as will be discussed later, in this paper, such a tactic may serve notice that the Justice's willingness to negotiate is limited and that he is quite ready to use whatever sanctions he feels necessary.

$$
\mathrm{X} \text {. }
$$

Winning majority endorsement of a given doctrine may be patently impossible in many situations. A Justice must then decide which available strategy offers the most promise. His major alternatives include:

(a) going along with the majority, trying to minimize through bargaining the damage done by the majority's refusal to accept the "true" doctrine or its acceptance of "false" doctrine;

(b) simply dissenting alone or with whoever will join in a particular case;

(c) trying to form a minority group of Justices into a voting bloc, at least for purposes of one set of issues.

Assuming that a Justice chooses alternative (c), how does he go about forming such a bloc? ? $_{120}$ Essentially, he may use the techniques, social and intellectual, discussed in previous sections of this paper. He can try to have "rightthinking" men appointed to the bench; he can use rational persuasion, social charm, and astute bargaining tactics. It is unlikely, however, that a Justice can truly create a bloc; more probably, the best he can do is to discover similar outlooks and voting tendencies among his colleagues and then use his social skills and intellectual power to reinforce ideological affinities.

118 Professor Glendon Schubert has been exploring the relevance of the game theory to certiorari decisions. See Schubert, QUaNtitative ANalysis of Judicial BeHavior 210-54 (1959), and Policy without Law: An Extension of the Certiorari Game, 14 STAN. L. REV. 284 (1962).

119 See SchelliNg, op. cit. supra note 1, at 19.

120 For discussions of "bloc analysis" see Pritchetr, The RoOsevelt Court (1948), and Civil Liberties and the Vinson Court (1954); Schubert, op. cit. supra note 118, ch. 3. 
One of the more obvious means of coalescing such a bloc is through the "rump conference"-a device used by Taft as .Chief Justice and Stone as an Associate Justice. Taft would call together Van Devanter and several of his other friends on the Court for Sunday afternoon meetings in his home. There the group would thrash over some of the more difficult cases and opinions so they could present a united front to their brethren. Some years later, to thwart Hughes' "efficient" disposal of business at conference, Stone held rump conferences in his home. These were conducted on Fridays with the purpose of hammering out in advance the important issues scheduled to be taken up in the next day's conference.

To keep the group together a Justice would have to be even more ready than he usually would to compromise-and to compromise quickly and amiably - with other bloc members as well as to accede to the judgment of bloc members on issues on which he was undecided or did not think important. This, however, is neither an absolute rule nor even necessarily a wise one. A minority bloc of four judges voting together has thirty-one out of thirty-two chances of winning any case; a bloc of three judges has approximately seven out of eight chances-praviding in each situation that no opposing blocs are formed among the other Justices. Thus it is highly desirable, and extremely difficult, to conceal the existence of such a bloc lest such knowledge move other Justices to efforts to form a counter-bloc.

It may therefore be better strategy if on many issues the bloc members vote against each other or at least concur in separate opinions. This task would be facilitated if there were some issues coming before the Court which all the bloc members considered trivial; then the members could agree to open and perhaps pitched disagreement as a smokescreen. Such divisions can also be made when the bloc has lost or when the majority is sufficiently large that defection of one or more bloc members will not affect the outcome. Dissenting votes in such cases should, of course, be explained on technical grounds so as both to mask the existence of the bloc and to enhance the Justice's reputation as a skilled craftsman who is a stickler for procedural niceties.

Although it is improbable that a group of Justices could long conceal their alliance from their colleagues or from outside observers using statistical analysis, even a gain in time of a few terms could be important in winning a significant victory. But the Justices must also consider substantive strategy. Clearly, bloc members should concentrate on wooing the Justice or Justices most likely to vote with them in a particular case. This aspect of strategy is far more obvious than some equally important facets. Where the votes required to achieve a majority on a decision are available but serious questions about overall policy are present, the bloc members might have to avoid taking a doctrinaire line either in conference discussion or in opinion writing. Their best plan might well be to discuss the case and write the opinion on relatively narrow grounds, hoping that if several such decisions follow each other over a 
period of years the underlying doctrine will seem to evolve naturally and not prematurely frighten an undecided Justice into rejecting the logical conclusions of the premises he has been accepting. It requires very delicate judgment to decide whether it is better to move when five votes are secured or to play for time, settling for an immediate but limited victory and wait until a sixth or a seventh vote can be picked up before announcing a controversial principle as the justification of a decision. One risk of a decision to wait is that the majority could also be lost in the interval. When the bloc members do decide to move, they will have two arguments to defend their newly captured position: first, the substantive reasons behind the principle and, second, an appeal to stare decisis, that touchstone of judicial virtue and regularity.

A bloc also faces major problems in voting on cases to be heard by the Court. It may be unwise to vote to grant certiorari in important cases where it is fairly certain that the bloc will be outvoted on the merits. There may be an exception in the extreme case which extends a doctrine beyond the point where the bloc members would be happy to have it end-at least for the time being. It would have been good strategy, for instance, for the four judge libertarian bloc of Black, Douglas, Murphy, and Rutledge to vote to review Chaplinsky v. New Hampshire. 121 In that case a Jehovah's Witness who had called a local police officer a "goddamned Fascist" and a "damned racketeer" was claiming the protection of the first amendment-an extension which none of the libertarians was willing to countenance. A group of Justices may vote to bring up an extreme case to help camouflage the existence of their bloc. For example, it would have been wise strategy for the group of Justices on the Warren Court who almost always vote in favor of workmen in FELA litigation to bring up an occasional case which they could in good conscience decide for the employer. ${ }^{122}$

A rational Justice would also have to plan anti-bloc tactics. A Justice who perceives opposing members of the Court uniting on some issues might utilize this information to bring together a counter-group. Once an opposing group has begun to coalesce, a Justice may try to break down its unity by pressing in conference discussion and in written opinions arguments on which he knows the bloc members disagree. ${ }^{123}$ Stone told Roosevelt that Hughes was particularly adept at using this maneuver against the liberal bloc on the old Court. When a difference of opinion was apparent among the liberals, the Chief Justice would, so Roosevelt recounted to Harold Ickes, "get his big toe in and widen the cleavage."124 Whether or not Stone's, or Roosevelt's, or Ickes'

121315 U.S. 568 (1942).

122 It has been suggested that this might have been done in Herdman v. Pennsylvania R.R., 352 U.S. 518 (1957); Schubert, op. cit. supra note 118, at 246-47.

123 There is another tactic available here, but one which is highly unethical. A Justice could sow distrust among bloc members by spreading gossip (false or true). This tactic could also be used-and be no less reprehensible-in almost all intra-Court relations.

1242 ICKES DIARIES 552 (1954). 
judgment and memory were affected by the bitterness of the Court fight over the New Deal, the fact remains that, from whatever motivation, Hughes was apt to assign opinions to liberals when the liberal bloc split and to conservatives when that group was divided.125

XI.

This paper has emphasized the opportunities for leadership and compromise within the Court. It goes without saying that some cases present issues of such fundamental importance to the basic values of American society that a Justice could not, indeed should not, even consider compromise. For the purposes of this analysis, it is enough merely to note that a Justice may sometimes be unable in good conscience to dilute his views or keep them to himself. What should be brought out here is that, matters of conscience aside, such an occasional rigid stand may also be tactically prudent.

To make the most of having to share decision-making authority with eight other men, a Justice would generally have to be willing to compromise, assuming his colleagues were men of comparable skill and firmness of character -unless, of course, he found himself in the happy position of being in a strong majority on all cases in which 'he had a deep interest. On the other hand, a Justice who was always ready to give in, to accept a half-loaf, could by that very fact weaken his bargaining potential. If he invariably accommodated himself to others on all issues, his colleagues might well cease to take his arguments seriously. To maintain the respect of the Court, a Justice would have to use his sanctions from time to time. It is hardly a novel observation that a successful public official must be feared as well as loved.

It is evident that what has been said in this paper does not provide a clear blueprint for a Justice to follow in making his legal views prevail. Nor could it be inferred that any combination of strategies and tactics could act as a viable substitute for wise judgment, intellectual acumen, technical craftsmanship, literary skill, or personal integrity. These are all-essential qualities of a good judge; but they are not always in themselves sufficient to secure acceptance of his public law aims. A Justice who deeply believed in his goals and who wished to attain them would have to consider, though he might well reject, such alternatives as have been discussed here.

125 Danelski has some interesting details in his two papers, supra notes 2 and 95. For examples of this tactic by Hughes, see also Brant, How Liberal Is Justice Hughes? 91 THE NEW REPUBLIC 295, 329 (1937). 